\title{
POPULATION RESOURCES OF AN ENDANGERED SPECIES Salix lapponum L. IN POLESIE LUBELSKIE REGION (EASTERN POLAND)
}

\author{
Magdalena Pogorzelec, Barbara Banach-Albińska, Artur Serafin, Agnieszka Szczurowska
}

\author{
Department of General Ecology, University of Life Sciences in Lublin \\ 20-680 Lublin, Leszczyńskiego 48, Poland \\ email:magdalena.pogorzelec@up.lublin.pl
}

Received: 05.06.2014

\begin{abstract}
This research, carried out in the years 2011-2013, aimed to evaluate Salix lapponum stands in the peat bogs of Polesie Lubelskie Region as well as to determine the condition of the population and the changes that have taken place since the 1950's. An inventory carried out in 25 stands of S. lapponum known from the literature shows that the number of its stands has decreased by $80 \%$ in Polesie Lubelskie Region. In all the confirmed locations, a decrease in population numbers was also found in relation to the data known from the literature since the 1950 's. In the majority of the population locations that were considered to be extinct, there were no significant changes in habitat conditions, and ecological succession and changes in hydrological conditions could have been the cause of habitat changes only at a few sites. In the light of the study, the preservation of the S. lapponum population in Polesie Lubelskie seems to be impossible if appropriate active conservation measures are not taken immediately. Because area-based conservation, which covers most of the habitats of the studied species, does not bring the expected results, the possibility of ex situ conservation and enlargement of the populations existing in the natural environment in peat bog ecosystems in Polesie should be explored.
\end{abstract}

Key words: Salix lapponum, endangered species, population, locations, abundance,sex ratio, peat bogs

\section{INTRODUCTION}

Salix lapponum is one of the most frequently mentioned valuable and rare glacial relict plant species in PolesieLubelskie Region. Downy willow has 'Red Data Book' status and is an endangered species (EN by IUCN) [1,2]. S.lapponum is an example of a species that inhabited in great numbers the wetland ecosystems of Polesie still in the 1950's. At that time, it was described by Fijałkowski as a species that was found very often in the peat bogs of this area. This author observed a clear relationship of the occurrence of S. lapponum with areas distant from large human settlements and vast areas not destroyed by human activities [3].

$S$. lapponum is a short shrub associated with transitional and raised bog habitats which, though quite common in Polesie, are under constant human pressure. Due to the transformation of the natural environment, many peatland habitats have lost their former character. Both the abiotic and biological environmental conditions have changed. Many peat ecosystems have been degraded or fragmented. Human activity, manifested mainly in the interference with water relations but also in the intensification of industry, agriculture and tourism, has led to the drying of wetlands and an accelerated process of ecological succession. All these changes result in the withdrawal of relict species from their natural stands. This process also applies to $S$. lapponum [4].

The aim of this study was to evaluate $S$. lapponum stands in the peat bogs of PolesieLubelskie Region and to determine the condition of the populations and the prospects for their further functioning in the study area.

\section{MATERIALS AND METHODS}

A field study was conducted in the peat-bogs of Łęczyńsko-Włodawskie Lakeland and the Sobibor Landscape Park (East Poland; Lubelszczyzna) during the growing season in the years 2011, 2012 and 2013. The first stage of the study involved the penetration of the areas where stands of the S. lapponum population have been observed in the past since the 1950's (a total of 25 stands, including 35 locations of the population) [3,5-8].

The stands identified in the area in 2011-2013, based on the literature data, were classified in the following way, after Churski and Danielewicz [9]: 
- "confirmed" - stands in which S. lapponum individuals were found (even if it was a single individual);

- "extinct" - stands where the population or individuals of S. lapponum were not found to occur, primarily due to a partial or complete change in the character of the habitats;

- "not confirmed" - stands where the presence of the population or single individuals was not observed, which was not caused by a change in the habitat but, e.g., an unclear description of the location of the stand in the literature, the lack of access to the stand or other objective or subjective reasons.

The exact location of the $S$. lapponum population was determined using a portable GPS device. The coordinates were determined for the central part of the stand where the population occured.

The number of $S$. lapponum individuals was determined (an individual was considered to be each aboveground shoot, regardless of underground connections).

The gender structure of the population was also determined, which was shown as the ratio of male to female individuals in the population (in the stands where blooming of $S$. lapponum was observed), and the height of shoots of all individuals in the studied populations (excluding seedlings which cannot be identified in the phytocoenosis structure).

\section{RESULTS}

The inventory carried out in $25 \mathrm{~S}$. lapponum stands known from the literature shows a $80 \%$ decrease in the number of stands of the studied species in Polesie Lubelskie Region. The existence of five $S$. lapponum stands (6 locations of the population; Fig. 1) was confirmed in the study area: in the peat bog near Lake Bikcze (the largest population - 301 individuals), in the peat bog near Lake Moszne (79), in the peat bog adjacent Lake Karaśne - two locations (a total of 31 individuals), in the peat bog near Lake Dlugie (14), and in the peat bog adjacent Lake Lubowierek (KrowieBagno - 6 individuals). In all the stands, a decline in the population was also found in relation to the data known from the literature since the 1950's (Table 1). Out of the $35 \mathrm{~S}$. lapponum locations known from the literature, 18 populations were considered to be extinct and 11 populations were not confirmed in the earlier described locations. In the majority of the stands that were considered to be "extinct", there were no significant changes in habitat conditions, only in 4 locations the succession of trees and shrubs could have been the cause of habitat changes, while in two locations significant changes in hydrological conditions were found. The stands classified as "not confirmed" were not found due to the difficult field conditions or an inaccurate description of the location of the stands - but the possibility of the occurrence of $S$. lapponum there is not excluded completely.

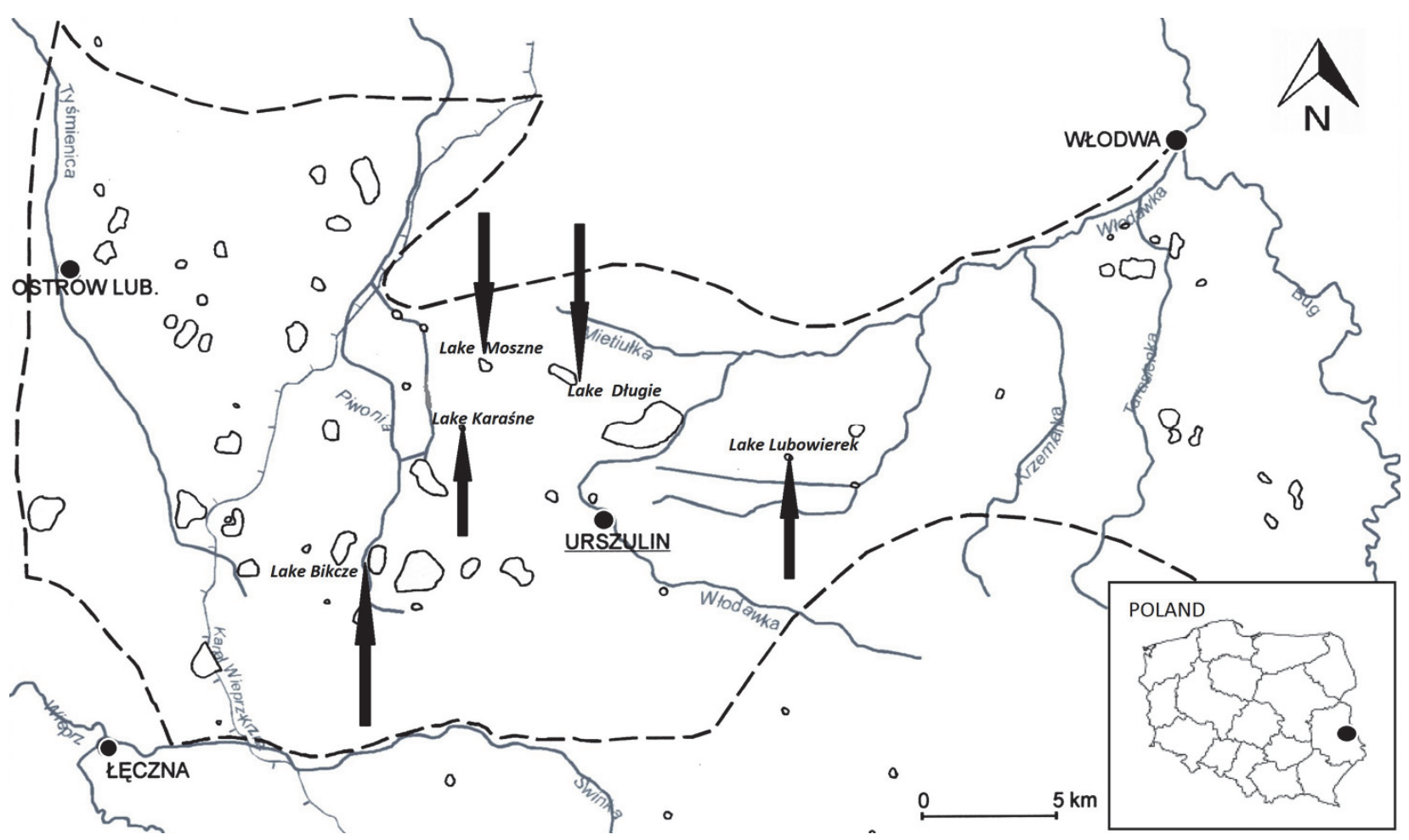

Fig. 1. Location of confirmed Salix lapponum stations in Eastern Poland. 
The determination of the gender structure was possible only in one population existing in the peat bog located on the western shore of Lake Bikcze; the ratio of males to females in this population was approximately $2: 1$. In the population growing in the peat bog near Lake Karaśne, only female specimens were recorded, whereas in the other populations plants were not observed to flower, which made it impossible to identify their gender (Tab. 1).
The height of each mature specimen in the populations varied significantly, but the highest specimens grew at the site in the peat bog near Lake Bikcze (up to $200 \mathrm{~cm}$, on average $78.02 \mathrm{~cm} \pm 26.22$ ). The average height of individuals at the other site was as follows: Lake Moszne $42.25 \mathrm{~cm} \pm 15.64$; Lake Karaśne $45.19 \mathrm{~cm} \pm 15.17$; Lake Długie $51.57 \mathrm{~cm} \pm 18.09$; Lake Lubowierek $38 \mathrm{~cm} \pm 12.93$.

Table 1

Historical Salix lapponum stands [3] and stands confirmed after 1990 [6-8,15] in PolesieLubelskie region in relation to the evaluation carried out in the period 2011-2013 ('nd' - no data).

\begin{tabular}{|c|c|c|c|c|c|c|}
\hline \multirow[b]{2}{*}{ Stands } & \multirow[b]{2}{*}{ Locations } & \multicolumn{2}{|c|}{$\begin{array}{l}\text { Previous studies }-\mathrm{N}^{\circ} \text { of } \\
\text { individuals }\end{array}$} & \multicolumn{3}{|c|}{ Present study (2011-2013) } \\
\hline & & 1958 & 2001-2009 & $\begin{array}{c}\mathrm{N}^{\circ} \text { of } \\
\text { individuals and } \\
\text { gender structure } \\
\left(0^{0}: \text { iq }\right)\end{array}$ & $\begin{array}{l}\text { Coordinates of } \\
\text { location }\end{array}$ & $\begin{array}{l}\text { Changes in } \\
\text { vegetation and } \\
\text { habitats }\end{array}$ \\
\hline \multicolumn{7}{|c|}{ Stands comfirmed } \\
\hline Krowie Bagno & $\begin{array}{c}\text { Peatbognear } \\
\text { Lubowierek Lake }\end{array}$ & nd & 33 & $\begin{array}{c}6 \\
\text { (no flowering) }\end{array}$ & $\begin{array}{l}\mathrm{N} 51^{\circ} 25.172^{\prime} \\
\mathrm{E} 023^{\circ} 19.096^{\prime}\end{array}$ & $\begin{array}{l}\text { No changes } \\
\text { observed }\end{array}$ \\
\hline Moszne Lake & $\begin{array}{l}\text { Peat bog on } \mathrm{N} \text { and } \mathrm{N}-\mathrm{W} \\
\text { shore of the lake }\end{array}$ & nd & $\begin{array}{l}\text { ca. } 100 \\
\text { individuals }\end{array}$ & $\begin{array}{c}79 \\
\text { (no flowering) }\end{array}$ & $\begin{array}{l}\mathrm{N} 51^{\circ} 27.653^{\prime} \\
\mathrm{E} 023^{\circ} 07.067^{\prime}\end{array}$ & $\begin{array}{l}\text { No changes } \\
\text { observed }\end{array}$ \\
\hline Długie Lake & S-E part of the peat bog & $\begin{array}{l}>2000 \\
\text { individuals }\end{array}$ & $\begin{array}{l}\text { ca. } 50 \\
\text { individuals }\end{array}$ & $\begin{array}{c}14 \\
\text { (no flowering) }\end{array}$ & $\begin{array}{l}\mathrm{N} 51^{\circ} 27.103^{\prime} \\
\mathrm{E}^{\circ} 23^{\circ} 10.299^{\prime}\end{array}$ & $\begin{array}{l}\text { No changes } \\
\text { observed }\end{array}$ \\
\hline Bikcze Lake & $\begin{array}{l}\text { Peat bog near the } \\
\text { western shore of the lake }\end{array}$ & $\begin{array}{c}10-50 \\
\text { individuals }\end{array}$ & $\begin{array}{l}\text { ca. } 5000 \\
\text { individuals }\end{array}$ & $\begin{array}{l}301 \\
(2: 1)\end{array}$ & $\begin{array}{l}\mathrm{N} 51^{\circ} 22.724^{\prime} \\
\mathrm{E} 023^{\circ} 02.563^{\prime}\end{array}$ & $\begin{array}{l}\text { Increased shrub } \\
\text { cover, changes } \\
\text { in hydrology }\end{array}$ \\
\hline \multirow{2}{*}{ Karaśne Lake } & $\begin{array}{l}\text { Peat bog near the S-W } \\
\text { shore of the lake }\end{array}$ & $\begin{array}{l}\text { Clusters of up } \\
\text { to } 10 \text { shrubs }\end{array}$ & nd & $\begin{array}{c}7 \\
\text { (no flowering) }\end{array}$ & $\begin{array}{l}\mathrm{N} 51^{\circ} 25.994^{\prime} \\
\mathrm{E}^{\circ} 23^{\circ} 06.239^{\prime}\end{array}$ & $\begin{array}{l}\text { No changes } \\
\text { observed }\end{array}$ \\
\hline & $\begin{array}{l}\text { Eastern part of the peat } \\
\text { bog }\end{array}$ & nd & $\begin{array}{c}\text { ca. } 60 \\
\text { individuals }\end{array}$ & $\begin{array}{c}24 \\
(0: 1) \\
\end{array}$ & $\begin{array}{l}\mathrm{N} 51^{\circ} 25.980^{\prime} \\
\mathrm{E}^{\prime} 23^{\circ} 06.576^{\prime}\end{array}$ & $\begin{array}{l}\text { No changes } \\
\text { observed }\end{array}$ \\
\hline \multicolumn{7}{|c|}{ Stands extinct } \\
\hline KrowieBagno & $\begin{array}{c}\text { PeatbognearLubowierz } \\
\text { Lake }\end{array}$ & $\begin{array}{l}\text { Clusters of up to } \\
10 \text { shrubs }\end{array}$ & nd & 0 & - & $\begin{array}{l}\text { No changes } \\
\text { observed }\end{array}$ \\
\hline Moszne Lake & $\begin{array}{l}\text { Peat bog on } \mathrm{N} \text { and N-E } \\
\text { shore of the lake }\end{array}$ & $\begin{array}{l}\text { about } 1000 \\
\text { individuals }\end{array}$ & nd & 0 & - & $\begin{array}{l}\text { No changes } \\
\text { observed }\end{array}$ \\
\hline Długie Lake & N-E part of the peat bog & $\begin{array}{l}\quad>100 \\
\text { individuals }\end{array}$ & nd & 0 & - & $\begin{array}{l}\text { No changes } \\
\text { observed }\end{array}$ \\
\hline Blizionki & $\begin{array}{l}\text { Mid-forest peat bog, W } \\
\text { of Lake Karaśne }\end{array}$ & 10 individuals & 5 individuals & 0 & - & $\begin{array}{l}\text { No changes } \\
\text { observed }\end{array}$ \\
\hline $\begin{array}{l}\text { Białe Sosnowickie } \\
\text { Lake }\end{array}$ & $\begin{array}{l}\text { Central part of the } \\
\text { western shore of the lake }\end{array}$ & $>100$ shrubs & nd & 0 & - & $\begin{array}{l}\text { No changes } \\
\text { observed }\end{array}$ \\
\hline $\begin{array}{c}\text { Czarne Gościnieckie } \\
\text { Lake }\end{array}$ & $\begin{array}{l}\text { Several meters from } \\
\text { S-W part of the lake } \\
\text { shore }\end{array}$ & $\begin{array}{l}\text { Clusters of up to } \\
10 \text { shrubs }\end{array}$ & nd & 0 & - & $\begin{array}{l}\text { Increased shrub } \\
\text { cover }\end{array}$ \\
\hline Miejskie Lake & $\begin{array}{l}\text { Western shore of the } \\
\text { lake (S-W part of the } \\
\text { peat bog) }\end{array}$ & $10-50$ shrubs & $\begin{array}{l}30(2005) \\
4(2009)\end{array}$ & 0 & - & $\begin{array}{l}\text { No changes } \\
\text { observed }\end{array}$ \\
\hline Gumienko Lake & $150 \mathrm{~m} \mathrm{~N}-\mathrm{W}$ of the lake & $\begin{array}{l}1000 \\
\text { individuals }\end{array}$ & nd & 0 & - & $\begin{array}{l}\text { Increased shrub } \\
\text { cover }\end{array}$ \\
\hline Wytyckie Lake & $\begin{array}{c}\mathrm{N} \text { and } \mathrm{W} \text { shore of the } \\
\text { lake }\end{array}$ & $10-50$ shrubs & nd & 0 & - & $\begin{array}{l}\text { Changes in } \\
\text { hydrology }\end{array}$ \\
\hline Łukie Lake & $\begin{array}{l}\text { The area of the whole } \\
\text { bog (mainly on the } \\
\text { eastern side) }\end{array}$ & $\begin{array}{l}10-50 \\
\text { individuals }\end{array}$ & nd & 0 & - & $\begin{array}{l}\text { No changes } \\
\text { observed }\end{array}$ \\
\hline
\end{tabular}




\begin{tabular}{|c|c|c|c|c|c|c|}
\hline Uściwierz Lake & $\begin{array}{l}\text { Peat bog on the western } \\
\text { shore of the lake }\end{array}$ & $50-100$ shrubs & nd & 0 & - & $\begin{array}{l}\text { No changes } \\
\text { observed }\end{array}$ \\
\hline Nadrybie Lake & $\begin{array}{l}\text { Peat bog near the } \\
\text { western shore of the lake }\end{array}$ & $10-50$ shrubs & nd & 0 & - & $\begin{array}{l}\text { Increased shrub } \\
\text { and tree cover }\end{array}$ \\
\hline $\begin{array}{l}\text { Spilno-Koseniec } \\
\text { Lake }\end{array}$ & Eastern shore of the lake & $>100$ shrubs & nd & 0 & - & $\begin{array}{l}\text { Changes in } \\
\text { hydrology }\end{array}$ \\
\hline \multirow{2}{*}{ Dubeczyńskie Lake } & $\begin{array}{c}\text { Western part of the peat } \\
\text { bog }\end{array}$ & $\begin{array}{c}\text { Clusters of up to } \\
10 \text { shrubs }\end{array}$ & nd & 0 & - & $\begin{array}{l}\text { No changes } \\
\text { observed }\end{array}$ \\
\hline & $\begin{array}{l}\text { Transitional bog, } \mathrm{W} \text { of } \\
\text { the lake }\end{array}$ & 7 individuals & nd & 0 & - & $\begin{array}{c}\text { No changes } \\
\text { observed }\end{array}$ \\
\hline BagnoWąskie & $\begin{array}{c}\text { Peatbog S of Lake } \\
\text { Wytyckie }\end{array}$ & $\begin{array}{l}\text { Clusters of up to } \\
10 \text { shrubs }\end{array}$ & nd & 0 & - & $\begin{array}{c}\text { Increased shrub } \\
\text { cover }\end{array}$ \\
\hline Orchowe Lake & $\begin{array}{l}\text { W of the lake, } \\
\text { transitional bog }\end{array}$ & nd & $\begin{array}{c}11 \\
\text { individuals }\end{array}$ & 0 & - & $\begin{array}{l}\text { No changes } \\
\text { observed }\end{array}$ \\
\hline Leśń. Dekowina & $\begin{array}{l}\text { Section } 244 a \text {, on the } \\
\text { edge of a small mid- } \\
\text { forest peat bog }\end{array}$ & nd & 6 clusters & 0 & - & $\begin{array}{l}\text { No changes } \\
\text { observed }\end{array}$ \\
\hline \multicolumn{7}{|c|}{ Stands not confirmed } \\
\hline $\begin{array}{l}\text { Forest District } \\
\text { Sobibór, } \\
\text { ForestryŻłobek }\end{array}$ & $\begin{array}{l}\text { Section 90a, the pea bog } \\
\text { N-W of Sobibór railway } \\
\text { station }\end{array}$ & nd & 20 clusters & 0 & - & $\begin{array}{l}\text { No changes } \\
\text { observed }\end{array}$ \\
\hline $\begin{array}{l}\text { Forest District } \\
\text { Sobibór, } \\
\text { Forestry Dekowina }\end{array}$ & $\begin{array}{l}\text { Section } 178 c \text {, } \\
\text { transitionalbog }\end{array}$ & nd & 5 clusters & 0 & - & $\begin{array}{l}\text { No changes } \\
\text { observed }\end{array}$ \\
\hline BagnoStaw & Peat bog & $\begin{array}{l}\text { Clusters of up to } \\
10 \text { shrubs }\end{array}$ & nd & 0 & - & $\begin{array}{l}\text { No changes } \\
\text { observed }\end{array}$ \\
\hline $\begin{array}{l}\text { Forest District } \\
\text { Sobibór, } \\
\text { Forestry Osowa }\end{array}$ & $\begin{array}{l}\text { Section } 268 \mathrm{~h}, 269 \mathrm{f} \text {, a } \\
\text { mid-forest marsh south } \\
\text { of DrogaBandycka (on } \\
\text { the northern edge of } \\
\text { the peat bog and in the } \\
\text { southern part) }\end{array}$ & nd & 29 clusters & 0 & - & $\begin{array}{l}\text { No changes } \\
\text { observed }\end{array}$ \\
\hline \multirow{5}{*}{$\begin{array}{l}\text { Forest District } \\
\text { Sobibór, } \\
\text { Forestry Macoszyn, } \\
\text { Kosyń }\end{array}$} & $\begin{array}{l}\text { Section } 299 \mathrm{a} \text {, in the } \\
\text { peat bog in the valley } \\
\text { of a small watercourse } \\
\text { (a tributary of the } \\
\text { Tarasienka River) in } S \\
\text { and N part of the peat } \\
\text { bog }\end{array}$ & nd & $\begin{array}{c}11 \\
\text { individuals }\end{array}$ & 0 & - & $\begin{array}{l}\text { No changes } \\
\text { observed }\end{array}$ \\
\hline & $\begin{array}{l}\text { Small mid-peat bog east } \\
\text { of PańskieBagna }\end{array}$ & nd & 9 clusters & 0 & - & $\begin{array}{l}\text { No changes } \\
\text { observed }\end{array}$ \\
\hline & $\begin{array}{l}\text { Section 301Ad, S part } \\
\text { of peat bog, near arable } \\
\text { land }\end{array}$ & nd & 8 clusters & 0 & - & $\begin{array}{l}\text { No changes } \\
\text { observed }\end{array}$ \\
\hline & $\begin{array}{l}\text { Section } 282 \mathrm{f} \text {, in the } \\
\text { center of a small mid- } \\
\text { forest peat bog in the } \\
\text { valley of a tributary of } \\
\text { Tarasienka River }\end{array}$ & nd & $\begin{array}{l}\text { ca. } 80 \\
\text { individuals }\end{array}$ & 0 & - & $\begin{array}{l}\text { No changes } \\
\text { observed }\end{array}$ \\
\hline & $\begin{array}{c}\text { Section } 345 b, N \text { part } \\
\text { of Buzornica Marsh, } \\
\text { peat bog bordering the } \\
\text { village of Kosyń }\end{array}$ & nd & $\begin{array}{l}\text { ca. } 30 \\
\text { individuals }\end{array}$ & 0 & - & $\begin{array}{l}\text { No changes } \\
\text { observed }\end{array}$ \\
\hline $\begin{array}{l}\text { Forest } \\
\text { DistrictSobibór, } \\
\text { Forestry Kosyń }\end{array}$ & $\begin{array}{l}\text { Section 365Ad, } \\
\text { BagnoSołtysy, } \\
\text { transitional bog }\end{array}$ & nd & $\begin{array}{l}\text { several } \\
\text { clusters }\end{array}$ & 0 & - & $\begin{array}{l}\text { No changes } \\
\text { observed }\end{array}$ \\
\hline $\begin{array}{l}\text { ForestryZbereże, } \\
\text { Brudno Lake }\end{array}$ & $\begin{array}{l}\text { Section } 242 k \text {, north of } \\
\text { the lake }\end{array}$ & nd & $\begin{array}{c}14 \\
\text { individuals }\end{array}$ & 0 & - & $\begin{array}{l}\text { No changes } \\
\text { observed }\end{array}$ \\
\hline
\end{tabular}




\section{DISCUSSION}

Originally, about 60 S.lapponum stands were reported in Poland, but now most of them are historical. In the 1990's, stands in the following locations were confirmed: Biebrza National Park, Knyszyńska Forest in the Stare Biele reserve, Polesie National Park, Łęczyńsko-Wlodawskie Lakeland (Polesie Lubelskie), and two stands in the Karkonosze Mountains [1].

The study conducted in 2011-2013 shows a significant decrease in the number of $S$. lapponum stands in Polesie Lubelskie. Out of the 25 stands (35 exact locations of the population) of the studied species known from the research of $\mathrm{Fij} \mathrm{a} \mathrm{k} \mathrm{ow} \mathrm{ski} \mathrm{[3]} \mathrm{and} \mathrm{from} \mathrm{the}$ later studies of $\mathrm{Urb}$ an and $\mathrm{W}$ a we r [6], only five were confirmed, which means an about $80 \%$ loss in the number of these stands.

The changes that have taken place in the natural environment of Polesie since the 1950's certainly have not been without effect on the functioning of the $S$. lapponum population in this area. In lowland areas, downy willow prefers wetland habitats in transitional bogs with communities from the class ScheuchzerioCariceteafuscae, with poor shrub cover $[1,8,10]$. Meanwhile, the progressive ecological succession in the peat ecosystems of Polesie goes in the direction of these ecosystems being overgrown by woody or expansive species (e.g. Salix cinerea, Betula pendula, Phragmites australis) which affect the habitat conditions and displace species with narrow ecological tolerances. In the areas where the phenomenon of accelerated succession has been observed, there has been a significant drying and shading of habitats, which has an effect on the proper functioning of the populations of peatland plant species. These processes are caused by natural factors only to a small extent, but more often are a result of many years of anthropogenic stress.

The hydrological conditions in Polesie Lubelskie, especially Łęczyńsko-Włodawskie Lakeland, have changed, while the processes of habitat degradation continue to progress despite the fact that large areas in this region have been covered by different forms of area-based conservation. Mining activities in the area as well as the functioning of the system of drainage ditches associated with the Wieprz-Krzna Canal have been causing the fragmentation of natural habitats and the destabilization of habitat conditions in the natural ecosystems of this area for many years [11-13].

The largest $S$. lapponum population of Łęczyńsko-Wlodawskie Lakeland exists in the peat bog near Lake Bikcze. In 2000-2004 the occurrence of about 5000 individuals of this species was recorded there [14]. The study conducted in 2011-2013 showed that the population had declined in 10 years by more than $90 \%$. This is alarming that the other four smaller populations probably do not function properly, what is reflected in the lack of flowering or inappropriate gender proportions in the structure of the population. Such a situation is probably due to intrapopulation processes, induced by isolation and changes in the habitats of the studied species, which have been taking place for a long time. Also, one cannot exclude the risk of invasion by foreign genes which may result from the crossing of S. lapponum with other species of willows co-existing in its stands [1,15-17].

The maintenance of the $S$. lapponum population in Polesie Lubelskie seems to be impossible if appropriate active conservation measures are not taken immediately. Because area-based conservation, which covers most of the habitats of the studied species, does not bring the expected results, the possibility of ex situ restoration and enlargement of the populations still existing in the natural environment in the peat bog ecosystems in Polesie should be analyzed.

\section{Acknowledgments}

The study was supported by the research grant N N 304385239 from the Ministry of Science and Higher Education of Poland.

\section{Authors' contributions}

The following declarations about authors' contributions to the research have been made: research design: MP; field study: MP, BB, AS, ASz; writing of the paper: MP.

\section{REFERENCES}

1. K r u szel n i ck i J. Salix lapponum L. (wierzba lapońska). In: Kaźmierczakowa R, Zarzycki K, editors. Polska czerwona księga roślin. Paprotniki i rośliny kwiatowe. Cracow: W. Szafer Institute of Botany, Polish Academy of Sciences; 2001: 73-75

2. Mirek Z, Zarzycki K, Wojewoda W, Szeląg Z. Czerwona lista roślin i grzybów Polski. Cracow: W. Szafer Institute of Botany, Polish Academy of Sciences; 2006.

3. Fijałkowski D. Badanianad rozmieszczeniem i ekologią wierzby lapońskiej (Salix lapponum L.) na Pojezierzu Łęczyńsko-Włodawskim. Fragm Flor Geobot. 1958; 3(2): 89-103.

4. R a dwan S, editor. Przyrodnicze podstawy ochrony i odnowy ekosystemów wodno torfowiskowych w obszarze funkcjonalnym Poleskiego Parku Narodowego na tle antropogenicznych przekształceń środowiska przyrodniczego. Lublin: Institute of Agrophysics, Polish Academy of Sciences; 2003. (Acta Agrophysica; vol 91).

5. Fijałkowski D. Szata roślinna jezior ŁęczyńskoWłodawskich i przylegających do nich torfowisk. Ann UMCS Sec B. 1959; 14: 131-203.

6. Urban D, Wawer M. Salix lapponum L. i S. myrtilloides L. w okolicach Sobiboru na Pojezierzu ŁeczynskoWłodawskim. Ann UMCS Sec E. 2001; 56: 83-93. 
7. Pogorzele c M. Influence of chosen environmental abiotic factors on Salix lapponum L. populations functioning in Polesie Lubelskie Region. Pol J Env. Stud. 2008; 17(4): 139-144.

8. Pogorzelec M. Downy willow (Salix lapponum L.) as a component of different phytocoenoses in Polesie National Park. Acta Agrobot. 2009; 62(1): 107-116. http://dx.doi.org/ 10.5586/aa.2009.013

9. Churski M, Danielewicz W. Salix myrtilloides in north central Poland. Distribution, threats and conservation. Dendrobiology. 2008; 60: 3-9.

10. Zarzycki K, Korzeniak U, editors. Ecological indicator values of vascular plants of Poland. Cracow: W. Szafer Institute of Botany, Polish Academy of Sciences; 2002.

11. Fijałkowski D, Izdebski K. Poleski Park Narodowy - flora naczyniowa. In: Radwan S, editor. Poleski Park Narodowy. Monografia przyrodnicza. Lublin: Morpol; 2002. p. 103-114.

12. Urban D, Gawlik J, Radwan S. The degree of differentiation in plant communities in different types of peatbogs. In: Przyrodnicze podstawy ochrony i odnowy ekosystemów wodno torfowiskowych w obszarze funkcjonalnym Poleskiego Parku Narodowego na tle antropogenicznych przekształceń środowiska przyrodniczego. Lublin: Institute of Agrophysics, Polish Academy of Sciences; Acta Agrophysica 2003; 91: 166-178.

13. B a ryła R, Fijałkowski D. Roślinność naczyniowa jezior i torfowisk w rejonie Poleskiego Parku Narodowego i jego otuliny. In: Radwan S, editor. Ochrona ekosystemów wodnych w Poleskim Parku Narodowym i jego otulinie. Lublin: TWWP; 1995: 79-84.

14. Pogorzele c M. The downy willow (Salix lapponum L.) population on the peat bog near Lake Bikcze (Łęczyńskowłodawskie Lakeland). Acta Agrobot. 2008;61(1):91-97. http://dx.doi.org/10.5586/aa.2008.012

15. Pogorzelec M. Salix lapponum L. (Downy willow) in stands under anthropopressure in the Łęczna-Włodawa Lakeland. Acta Agrobot. 2010; 63(1): 47-54. http://dx.doi. org/10.5586/aa.2010.006

16. Pogorzelec M, Banach B. The occurence of rare and protected plant species on the peat bog near Lake Bikcze (Łęczyńsko-Włodawskie Lakeland). Acta Agrobot. 2008; 61(2): 113-120. http://dx.doi.org/10.5586/aa.2008.039

17. Pogorzelec M, Now osielski J. The Salix lapponum L. (downy willow) among-population genetic diversity in the Polesie Lubelskie Region. Ann UMCS Sec B. 2006; 61(4): 99-106.

\section{Zasoby populacji zagrożonego gatunku Salix lapponum L. na Polesiu Lubelskim (Wschodnia Polska)}

\section{Streszczenie}

Badania prowadzone w latach 2011-2013 miały na celu waloryzację stanowisk Salix lapponumna torfowiskach Polesia Lubelskiego, określenie stanu populacji oraz zmian jakie zaszły od lat $50 . \mathrm{XX}$ w. Inwentaryzacja przeprowadzona $\mathrm{w}$ znanych $\mathrm{z}$ danych literaturowych 25 stanowiskach $S$. lapponum wskazuje na spadek o około $80 \%$ liczby stanowisk badanego gatunku na terenie Polesia Lubelskiego. We wszystkich potwierdzonych stanowiskach odnotowano również spadek liczebności populacji w stosunku do danych znanych z literatury od lat 50. XX w. W większości stanowisk populacji, które uznane zostały za wymarłe nie zanotowano znacznych zmian w warunkach siedliskowych, tylko w nielicznych stanowiskach przyczyną zmian habitatowych mogła być sukcesja ekologiczna, oraz zmiany w warunkach hydrologicznych. W świetle przeprowadzonych badań zachowanie populacji Salixlapponum na terenie Polesia wydaje się być niemożliwe, jeśli nie zostaną podjęte niezwłocznie odpowiednie kroki w celu jej ochrony czynnej. Ponieważ ochrona obszarowa, której podlega większość siedlisk badanego gatunku, nie przynosi oczekiwanych rezultatów, należy prowadzić działania w kierunku ochrony gatunkowej ex situ oraz zasilania populacji funkcjonujących w naturalnym środowisku.

Handling Editor: Elżbieta Weryszko-Chmielewska

This is an Open Access digital version of the article distributed under the terms of the Creative Commons Attribution 3.0 License (creativecommons.org/licenses/by/3.0/), which permits redistribution, commercial and non-commercial, provided that the article is properly cited.

(C)The Author(s) 2014 Published by Polish Botanical Society 